\title{
História e memória do percurso educativo de Célia Goiana
}

\section{History and memory of the educational path from Célia Goiana}

\section{Historia y memoria de la trayectoria educativa Célia Goiana}

\author{
Lia Machado Fiuza Fialho ${ }^{1}$ \\ Scarlett O'hara Costa Carvalho ${ }^{1}$
}

DOI: http://dx.doi.org/10.20435/serie-estudos.v22i45.992

\begin{abstract}
Resumo: O objetivo foi compreender as práticas educativas, leituras e representações que eram tecidas pela educadora Célia Goiana, uma professora cearense que participou ativamente do processo educativo do estado. O percurso metodológico utilizado na pesquisa foi a história oral biográfica, com ênfase na trajetória formativa e educativa. A entrevista híbrida, gravada, transcrita, textualizada e validada foi utilizada como fonte primária e associada a outras fontes secundárias - documentos pessoais, prêmios e fotos - com o intuito de desvelar os meandros pertinentes à história e à memória da educação no Ceará na primeira metade século XX. Os resultados demonstraram que Célia Goiana foi uma educadora à frente de seu tempo, pois rompeu paradigmas sociais ao se dedicar à educação e contrariar os anseios de seus pais, que pretendiam formar uma filha médica, principalmente quando atuou nas classes menos favorecidas, mesmo possuindo uma formação educativa elitizada. Ela se dedicou com afinco à profissão docente, atuando na educação infantil, com alfabetização de crianças; no ensino fundamental, com escolas em comunidades carentes e em colégios mais elitistas; e no nível superior, com formação de profissionais para o magistério. Nesse nível de educação, consagrou-se personagem de referência para a história do Curso de Pedagogia da Universidade Estadual do Ceará; suas memórias imortalizam não apenas a história do curso, mas da própria instituição, que não possuía o cuidado de arquivar documentos.
\end{abstract}

Palavras-chave: práticas educativas; biografia; educação; memória.

Abstract: The aim of this study was to understand the educational practices, readings and representations that were woven by educator Célia Goiana, one teacher from Ceará who actively participated in the education process of the state. The methodological approach used in the research was biographical oral history, with emphasis on training and educational trajectory. Hybrid interview recorded, transcribed, textualized and validated was used as a primary source and associated with other secondary sources - personal documents, awards and photos - in order to uncover the facts pertaining to the history and education of memory in Ceará in the first half century XX. The results showed that the educator Célia Goiana was ahead of her time because she broke social paradigms to devote to edu-

${ }^{1}$ Universidade Estadual do Ceará (UECE), Fortaleza, Ceará, Brasil. 
cation and be against the wishes of her parents who wanted to form a medical daughter, especially when she served in the lower classes even having an elitist educational training. She dedicated herself in a very hard way to the teaching profession, working: in early childhood education, with literacy of children; in primary education, with schools in poor communities and school more elitist; and at the higher level, training professionals for teaching. At this level of education, was consecrated reference character to the story of UECE at Education Course, your memories immortalizing not only the story of the course, but also the own institution, which did not have attempted by archiving the documents.

Key words: educational practices; biography; education; memory.

Resumen: El objetivo era comprender las prácticas educativas, lecturas y representaciones que se tejieron por la educadora Célia Goiana un maestro cearense que participó activamente en el estado del proceso educativo. El enfoque metodológico utilizado en la investigación fue la historia biográfica oral, con énfasis en la formación y la trayectoria educativa. entrevista híbrido, grabada, transcrita, textualizada y validado, se utilizó como fuente primaria y asociada con otras fuentes secundarias documentos personales, premios y fotos - con el fin de revelar las complejidades relevantes de la historia y la memoria de la educación en Ceará primera mitad del siglo XX. Los resultados mostraron que Célia Goiana fue un educador delante de su tiempo, ya que rompió paradigmas sociales para dedicarse a la educación y la lucha contra los deseos de sus padres, que querían formar una hija médico, especialmente cuando se sirve en las clases más bajas, ni siquiera tener una entrenamiento educativo elitista. Ella se dedicó difícil de la profesión docente, en calidad: en la educación infantil, con niños de alfabetización; en la enseñanza primaria, con las escuelas en las comunidades pobres y colegios de élite; y en el nivel superior, con la formación profesional de los maestros. En este nivel de educación, era el carácter de referencia dedicada en la historia de la Universidad Estatal de Ceará Escuela de Educación; inmortalizar sus recuerdos no sólo la historia, por supuesto, pero la propia institución, que no tienen el cuidado de los documentos de archivo.

Palabras clave: prácticas educativas; biografía; educación; memoria.

\section{INTRODUÇÃO}

"História e memória do percurso educativo de Célia Goiana" foi um subprojeto da pesquisa "guarda-chuva" denominada Educação e educadores(as) no Ceará do século XX: práticas, leituras e representações, institucionalizada pela Universidade Estadual do Ceará (UECE), aprovada pelo Comitê de Ética em Pesquisa (CEP) sob parecer de número 630.923, de 21 de março de 2014, e apoiada financeiramente pelo Conselho Nacional de Desenvolvimento Científico e Tecnológico (CNPq) e pela UECE.

A pesquisa em relato foi desenvolvida no período de julho de 2014 a junho de 2015. O estudo teve como escopo compreender as práticas educativas, leituras e representações que eram tecidas pela docente Célia Goiana, uma professora que participou ativamente da educação no estado do Ceará. Esta investigação foi desenvolvida por intermédio da metodologia da história oral biográfica, que possibilitou 
constituir a trajetória formativa e educativa de Célia Goiana, bem como analisar suas representações acerca da educação cearense na primeira metade do século XX, desde a percepção relatada pelas narrativas oralizadas, provenientes da memória da entrevistada.

Ressaltar as contribuições e dificuldades do fazer pedagógico, considerando o cenário econômico, social e educacional do Ceará, configurou-se relevante por possibilitar o trabalho com memórias e narrativas de pessoas que vivenciaram acontecimentos importantes na história da educação cearense e por permitir outro olhar acerca dos fatos narrados pela história oficial (FERREIRA; AMADO, 2006), ao confrontar percepções e até ressignificar padrões naturalizados no imaginário social.

Com apoio teórico nas contribuições trazidas pela Nova História Cultural (CERTEAU, 2002; CHARTIER, 1988), os estudos biográficos no campo da educação se configuram relevantes porque possibilitaram a investigação das práticas educativas empreendidas no imbricamento com questões sociopolíticas, além de propiciarem um acervo da história da educação no Ceará, valorizando o trabalho de educadoras que nem sempre desfrutaram da devida visibilidade na narrativa histórica.

\section{METODOLOGIA}

A metodologia da história oral biográfica é capaz de fomentar importantes narrativas e interpretações históricas, em especial no campo da história da educação do Ceará. Cabe inferir que a fonte oral é não apenas importante, mas necessária para a compreensão historiográfica, principalmente em um estado que não preserva as fontes documentais, tampouco arquivos imagéticos no âmbito educacional. Assim, cabe ao pesquisador, em face das fontes oficiais de que dispõe, elaborar novas perguntas sobre o passado, ou seja, reler alguns tipos de documentos oficiais considerando outras perspectivas e produzir novas fontes e interpretações (BURKE, 1992).

Como o homem não é um ser isolado, mas social, e suas ações interferem no contexto sociocultural, a história cultural é ensejada e uma pesquisa biográfica, realizada com os devidos critérios de seriedade acadêmica, contextualizada e analisada com tessitura, torna-se um significativo documento histórico (SILVA, 2009).

É possível, por meio da análise das vivências e práticas pedagógicas, fomentar o debate educacional e compreender melhor a postura didática no fazer pedagógico da atualidade. Observa-se, contudo, que uma biografia não possibilita generalizações ou macroexplicações, não explica o coletivo, assim como o coletivo não explica o individual (LORIGA, 2011). 
Esta pesquisa, nesse sentido, abordou especificamente a história oral biográfica com uma educadora idosa que contribuiu no contexto educacional da cidade de Fortaleza, CE, o que implica compreender, com maior clareza, a relevância da história de vida para a educação e de estudos com ênfase na preservação da história e memória individual e social (FIALHO, 2015). A relevância em biografar idosos (BOSI, 1994) - com a utilização da narrativa oral gravada, transcrita, transcriada e analisada criteriosamente-, seguindo um projeto previamente delineado no âmbito da história oral, justifica-se como temática de debate acadêmico por se constituir uma metodologia relativamente discutida e consensual, e recentemente adotada em inúmeras pesquisas (MEIHY; RIBEIRO, 2011).

A história oral, ao trabalhar com lembranças e esquecimentos, subjetividades, abordando um universo de significados, significações, ressignificações, representações psíquica e social, simbolizações, simbolismos, percepções, pontos de vista, perspectivas, experiências de vida e analogias (TURATO, 2003), não objetiva uma verdade histórica, mas sim ampliar a compreensão. Ela se define pelo "[...] resultado de experiências que vinculam umas pessoas às outras, segundo pressupostos articuladores de construções de identidades decorrentes de memórias expressadas em termos comunitários" (MEIHY; HOLANDA, 2007, p. 27).

A metodologia em tela se configura relevante para o desenvolvimento de investigações históricas, antropológicas, sociológicas, educacionais e de outros campos do saber, por possibilitar o trabalho com memórias e narrativas de pessoas que vivenciaram acontecimentos importantes da história, pois permite outro olhar acerca dos fatos narrados pela história oficial (FERREIRA; AMADO, 2006) ao perceber a realidade social como uma elaboração também cultural.

Ante a explicitação da metodologia adotada, importa salientar que, neste artigo, o sujeito biografado foi a educadora Célia Goiana, que atua como docente do Curso de Pedagogia do Centro de Educação da UECE há 37 anos, trabalhou, ainda, em outros estabelecimentos educativos por mais de 15 anos. Tempo que the rendeu memórias ricas e de fundamental importância para compreender a história do referido curso, bem como a história da educação no Ceará.

$\mathrm{Na}$ condição de uma das mais antigas professoras do curso supracitado, ainda no exercício das atividades acadêmicas, Célia se mostrou não apenas disponível a colaborar com o estudo, mas se manifestou alegre ao saber que poderia ajudar na elaboração da história do Curso de Pedagogia e ao ter ciência de que à sua voz seria ensejada maior visibilidade. Era uma oportunidade de ter também sua história como educadora registrada para a posteridade. 
Foi, todavia, por intermédio da história oral biográfica de Célia Goiana, coletada na UECE em uma sala reservada antecipadamente para essa finalidade, local selecionado pela conveniência da entrevistada, que se colheram as fontes primárias para a pesquisa. Por meio de três entrevistas, com cerca de 80 minutos cada uma - gravadas, transcritas, textualizadas e validadas -, buscou-se desvelar os meandros pertinentes à história com vistas a compreender as práticas educativas, leituras e representações que eram tecidas pela educadora cearense na primeira metade século XX.

\section{RESULTADOS E DISCUSSÕES}

Foi realizada, dessa maneira, uma biografia de Célia Goiana, que exprimiu sua história de vida com ênfase em sua trajetória formativa e educativa, mediante lembranças narradas das suas vivências de escolarização e atuação profissional no magistério. As práticas educativas, leituras e representações desenvolvidas por Célia, na elaboração de sua identidade como educadora, foi escopo mister.

Célia Maria Goiana Falcão nasceu em 6 de maio de 1951, filha de Terezinha de Castro Goiana Falcão e de José Maria Goiana Falcão. Possui dois irmãos, Francisco José de Castro Goiana Falcão e João Cézar de Castro Goiana Falcão, mas, ainda assim, sempre foi tratada como se fosse filha única, por ser a única menina da casa, ou seja, desfrutou de muito mimo e "paparicação" dos pais e avós. Para Philippe Ariès (1978, p. 159), a "paparicação" pode ser percebida tanto na atenção e valorização das ações infantis quanto no repúdio de outras pessoas adultas, mais rabugentas, que "consideravam insuportável a atenção que se dispensava, então, às crianças [...]".

Célia começou sua escolarização em uma escolinha pequena que se localizava próximo à sua casa no interior do Ceará. Sua família valorizava a educação e o estudo, por isso Célia procurava sempre ser boa aluna; alegava conseguir obter ótimos resultados. Comenta que, mesmo se saindo bem na escola, sempre teve um acompanhamento com professora particular para sanar suas dúvidas e lhe incentivar nos estudos. Essa regalia era decorrente também do fato de sua família possuir boas condições financeiras, o que possibilitava, sem muitos esforços, o desembolso do pagamento para aulas particulares.

A educadora recorda que veio para Fortaleza por volta dos cinco anos de idade e que, antes disso, já possuía uma pessoa indo diariamente à sua casa para acompanhar seus estudos, como narra:

Quando eu cheguei aqui, a titia [Filomena] me matriculou na escola que era em frente à casa onde eu morava, Justiniano de Serpa. Era uma série antes da 
alfabetização, acho que eu tinha uns cinco anos de idade. Ao mesmo tempo, eu estudava com a Dona Rita, que era uma professora particular, aí depois quem substituiu a Dona Rita foi um menino chamado Francisco de Assis. Ele me ensinava matemática, eu tinha muita dificuldade em matemática, mesmo quando estudava no Colégio Cearense [ensino médio].

O primeiro ano de escolarização de Célia no Justiniano de Serpa foi bastante curioso, pois ela foi matriculada no jardim II (atual infantil V), série compatível com sua idade cronológica, mas passava toda a aula na porta da sala assistindo à aula da sala da frente, que era de alfabetização (atual 10 ano do ensino fundamental). O desinteresse de Célia pelo jardim II decorria do fato de ela já ter sido iniciada na alfabetização pela professora particular e por dominar precocemente a escrita e a leitura. Quando as professoras identificaram a situação, passaram Célia para a alfabetização. Ela lia tão bem que foi escolhida para ser a oradora da turma na festa de fim de ano, tradicionalmente denominada de Doutor do ABC.

Terminado o primário (atual ensino fundamental I), Célia foi estudar no Colégio Batista, mas só passou dois anos nessa escola, por motivos religiosos. Os familiares acharam que o referido colégio não dava a importância necessária à formação cristã. Célia narra essa experiência:

Eu estudei no Colégio Batista no 2 o ano [atual 2a série], e a titia sempre fazia um interrogatório de como havia sido meu dia. Sempre me perguntava como eram as aulas. A mamãe me tirou da escola por causa da religião. Eles todos os dias passavam um filme sobre religião. Mas o lado mesmo formativo sobre a religião eles não ensinavam. Aía titia ligou para a minha mãe no Rio de Janeiro, e a mamãe me tirou de lá. A titia queria me colocar em um colégio para o qual eu quisesse ir. E assim fui para o Colégio Cearense no meu 3o ano [atual 3a série], mas estudei outro ano, por conta do cursinho de lá, que era muito bom.

Célia explicita o que sua mãe, avó e tias valorizavam na educação escolar quando afirma que o importante era a formação religiosa e para cuidar da casa: "além do comum, eu estudava português, teatro, francês, educação para o lar, costura, culinária e também pintava garrafas artísticas. Graças a essas aulas, eu casei, senão eu não saberia pregar um botão [risos]".

A educação para as prendas do lar, para o exercício da maternidade e para a subserviência ao marido era comum nesse período. As moças deveriam ser educadas para arranjar um bom casamento, saber se comportar com discrição na sociedade e administrar os afazeres do lar, comportamento esse cobrado pela sociedade e estimulado pela igreja, reforçado também pela divulgação de uma verdadeira pedagogia 
do casamento, que estabelecia as funções e os domínios específicos de homens e mulheres:

A função da mulher consistia em casar, gerar filhos para a pátria e plasmar o caráter dos cidadãos de amanhã; ao homem cabia a representação legal da família, a administração dos bens comuns do casal e dos particulares da esposa segundo o regime matrimonial adotado, o direito de fixar e mudar o local de domicílio da família, além de ser responsável pela manutenção da família. A ele, a identidade pública; a ela, a doméstica. (MALUF; MOTT, 1998, p. 374).

A saída das mulheres do reduto do lar para o trabalho e para a escola, enfim, para a sociedade produtiva, foi marcada pela desigualdade de possibilidades e pela separação entre profissões masculinas ativas e femininas sedentárias, num processo de naturalização da divisão sexual do trabalho. Quando houve uma ascensão das mulheres, foi acompanhada de uma evolução masculina. Esses avanços não se deram de forma tão amistosa nem facilitada, mas sim num contexto marcado por tensões e utilização de estratégias, por parte da sociedade em geral, para afastar a mulher do mercado de trabalho. Estratégias muitas vezes camufladas por boas intenções. Se as mulheres iam se integrando cada vez mais ao sistema educativo e ao mercado laboral, ocupavam, entretanto, os postos mais feminizados, hierarquicamente mais baixos e, consequentemente, desvalorizados. Em termos, foi assim que se deu a feminização do magistério (MACHADO, 2005).

Contrapondo-se à feminização do magistério, o pai de Célia não queria que a filha fosse dependente financeiramente de marido. Ele não valorizava demasiadamente o casamento e não Ihe arranjava pretendentes. Sonhava que a filha fosse médica.

Quando Célia tinha14 anos, sua mãe foi morar com o marido, pai de Célia, no Rio de Janeiro. Foi nesse período que ela ficou morando com suas quatro tias e com seu avô paterno, sem a presença dos pais. Foi ainda na condição de estudante do Colégio Cearense que Célia teve sua iniciação no trabalho docente, com quase 15 anos, quando teve seu primeiro contato com o magistério. Sobre isso, ela relata:

Eu trabalhei como voluntária em uma escola que existe ainda hoje, fui indicada por um diretor, onde todos eram amigos da minha tia, assim ninguém se prejudicava. Fui dar aula no Senai [Serviço Nacional de Aprendizagem Industrial], uma escola profissionalizante para adultos. Fui dar aula para gente como se fosse alfabetização, mas a nível de $3 \underline{a}$ série [atual 40 ano do ensino fundamental]. Quando a titia ficou boa, não me desapeguei disso, continuei ajudando-a, pois ela saiu do Senai e foi transferida para Escola Marcílio Dias. 
Sua primeira experiência no magistério foi como substituta de sua tia, que teve que se ausentar por motivo de saúde. Célia, então, ficou no lugar da tia, lecionando para adultos conteúdos compatíveis com os da série de alfabetização. Ela conta que a Escola Marcílio Dias era localizada na periferia, possuindo, portanto, uma clientela muito pobre. Sobre sua experiência nessa instituição, ela menciona um episódio em que recebeu o conselho de outra professora, que então lhe dissera: "A senhora venha bem simples". Quando ia para a Escola Marcílio Dias, Célia escondia seu carro atrás de uma igreja para ninguém ver que ela tinha posses, não por medo de assalto, e sim por receio de que as pessoas achassem que ela era rica, diferente, o que poderia fazer com que elas não se portassem da forma espontânea como costumavam agir normalmente. Célia possuía uma Brasília - na época um bom carro - que havia ganhado do pai.

Ainda sobre essa experiência, Célia recorda com detalhes de um fato que marcou sua vida e que condicionou sua opção pela carreira no magistério:

Um dia eu fui conhecer as casas [dos alunos da escola]. Eram muito simples, eram casas pequenas; as redes eram enroladas no teto; no canto, tinha tijolos brancos fazendo fogo, tinha uma panela velha toda machucada, e eles faziam doces de lata, doce de goiaba, doce de banana, que hoje em dia vêm naqueles plásticos. Faca não vi, colher não vi. Então, como uma criança dessas podia ter uma unha limpa, um cabelo cortado? Então, levei uma amiga minha para fazer um tratamento nos meninos; fiquei muito triste. Foi quando eu compreendi que uns nascem para ser felizes e outros nascem sem ter nada. Minha avó me disse: 'O mundo é imperfeito para que as pessoas se tornem perfeitas, Deus fez o mundo perfeito, mas o homem, com sua ambição, tornou o mundo imperfeito'. Então, eu vi que existia diferença entre as pessoas; para mim, foi bom, foi muito rico.

Foi desde essa vivência que Célia começou a perceber com outra perspectiva a realidade socioeconômica de Fortaleza e passou a compreender que a vida, para a maioria das pessoas, era bem diferente da que ela desfrutava, confirmando o pensamento de sua avó. Tal acontecimento impulsionou sua escolha profissional pelo magistério, o que contrariava o sonho de seu pai de ter uma filha médica. Sobre esse momento, ela esclarece:

O único pecado que eu cometi na vida foi ter mentido para meu pai nessa época. Eu estudei, tinha capacidade para passar em Medicina, porque eu estudava muito, mas, na hora da prova, fiz todos os cálculos e deixei 15 questões em branco. Não marquei. Mas, ainda assim, eu fiquei como classificável, porque, quando a gente sabe, a gente não controla. Deixei essas questões em branco porque eu não queria passar. 
Após esse momento de decepção para seu pai, Célia ficou sabendo da abertura do vestibular para a Universidade de Fortaleza (Unifor), única instituição privada de ensino à época que atendia a uma clientela de classe alta. Então, resolveu "criar coragem" para enfrentar o pai e falar sobre o que tinha escolhido para sua vida profissional:

Eu disse para ele que tinha muita vontade de fazer Pedagogia, e ele ficou com raiva, disse que eu queria ser como minha tia Maria das Dores, que iria passar fome, porque professora não ganhava dinheiro. Chorei muito. Mas disse a ele que iria ser a melhor e questionei: 'O melhor não ganha bem? Então, vou ser a melhor e vou ganhar bem!'.

Em 1973, Célia fez o vestibular para Pedagogia. Ela lembra esse momento com emoção - seu sorriso despontava e seus olham brilhavam - e enfatiza que "[...] iria ser a melhor que pudesse, mesmo que começando de baixo". A seu pai restou aceitar a decisão da filha. Ainda que não fosse seu desejo, soube respeitar a escolha de Célia e não apenas permitiu, mas também pagou a licenciatura dela em Pedagogia na Unifor.

O primeiro emprego regularizado oficialmente de Célia foi de professora; ministrava aula numa escola localizada na Avenida Dom Luís (a escola fechou, e Célia não recordava o nome da instituição). A dona vendeu a escola e, nas palavras da protagonista deste estudo: "[...] eu fui vendida junto". Isso porque algumas funcionárias fizeram entrevistas para trabalhar no colégio que havia comprado a escola, mas somente Célia e outra professora passaram na seleção. A instituição foi vendida para a escola General Osório, onde Célia continuou a atuar como professora alfabetizadora. Nessa época, Célia morava no Bairro Meireles, no qual residiu por 30 anos.

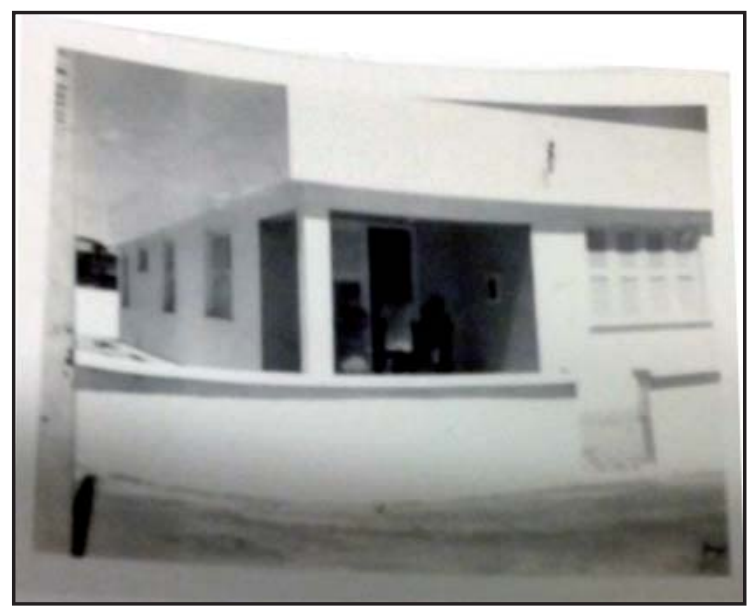

Imagem 1 - Casa onde Célia viveu por 30 anos

Fonte: Arquivos pessoais da entrevistada. 
Sobre sua época de graduação, conta um pouco de como era sua rotina:

Eu estudava à noite. De dia, na escola, eu negociava assim: 'Eu vou sair às 9 h, aí eu vou dar aula de 9hàs 11h. Quando for 11h30, estarei de volta no colégio e só saio às 19h30'. Tudo meu era assim. Eu não queria dever favor a seu ninguém. E com isso eu não dava motivo de nenhuma pessoa apontar o dedo para mim, coisa que eu detesto. Então, foi ficando uma conciliação de tal maneira que eu me dei bem.

Em 1977, Célia foi convidada para ser coordenadora do Colégio São João. Recorda: "Era um colégio que, se você falar para as pessoas antigas, elas vão falar que era o pior colégio. Ficava ali na Santos Dumont; hoje em dia é uma igreja". Célia não passou muito tempo lá, sendo, em 1978, convidada para supervisionar o Colégio Imaculada Conceição, que era referência de ensino de qualidade na cidade. Ela supervisionava do jardim até a 4 a série (infantil e primeiras séries do ensino fundamental atualmente).

O Colégio Imaculada Conceição era administrado por uma congregação religiosa, Filhas da Caridade de São Vicente de Paula, o qual teve grande notoriedade na história da educação da cidade de Fortaleza. Essa escola, gerida por freiras, não apenas formava as moças das classes mais abastadas do município, como também representava, no imaginário social, um espaço de socialização, preservação e educação das jovens, futuras donas do lar. Ao contrário do Colégio São João, o Imaculada Conceição era concebido como a melhor escola da cidade para o público feminino.

Ajudando à irmã que coordenava a escola sempre que possível, Célia, às vezes, passava o dia todo na instituição. Almoçava com as irmãs e ficava para dar uma ajuda quando tinha alguma celebração. Ela reitera que gostava muito da escola e das irmãs, mas houve um fato que a fez sair da escola:

Antes das férias, eu adoeci, e o médico pediu uns exames. Aí eu fui falar com a irmã diretora, para negociar, para ela me liberar. Era só o tempo para eu fazer o exame, que era pela manhã, em jejum. E ela olhou para mim e disse: 'Célia, você está muito corada, você não tem doença'. E eu apenas respondi, não discuti: 'Está bom, irmã, muito obrigada'. Nas férias, viajei e falei a meu pai: 'Papai, eu vou sair do colégio. Quero que você banque minha vida durante seis meses até eu arranjar um outro trabalho'.

Sobre a saída de Célia do Colégio Imaculada Conceição, a resposta do pai foi a seguinte: "Saia! Porque freira, quando dá para ser ruim, não muda". José Maria concordou em ajudá-la sem hesitação, mandando-lhe mesada regularmente, hábito 
que perdurou por muitos anos, pois, ainda em 1982, depois de Célia ter conseguido outros trabalhos e ter casado, ele ainda enviava o dinheiro para a filha.

Célia explica que a atitude do pai decorreu do fato de ele ter passado três meses no seminário com o intuito de ser padre, mas teve uma decepção com o Monsenhor e, justamente nesse período, conheceu aquela que seria a mãe de Célia, resolvendo, então, abandonar o seminário. Quanto à decepção de seu genitor com o padre, Célia relata:

Meu pai um dia estava rezando, escondendo o terço, porque ele tinha vergonha e estava chorando com saudade da família, porque ele ainda era novo. Aí tinha um padre vigiando. Esse padre levantou e falou: 'O que é que você está fazendo aí? Por acaso, você está pecando? Se masturbando?'. Papai falou que foi um susto e uma decepção. No outro dia, ele ia à catedral, e ali daquele lado tinha umas casas de repouso onde as mulheres ficavam com os seios à mostra na janela. O papai falava que o Monsenhor só brigava, e que, quando ele se atreveu a olhar, viu que o Monsenhor estava de olho nos peitos das mulheres. Ai papai disse: 'Bom, então se ele pode ser pecador, eu prefiro ser pecador com uma mulher'. Ele, que já conhecia a mamãe, só de vista, mas conhecia, resolveu ir atrás dela. Papai questionava muita coisa da igreja católica.

Com o apoio do pai, Célia decide deixar a escola. Ela não quis discutir sobre a importância de cuidar da saúde e de fazer os exames, tampouco mencionou a decepção, apenas alegou que era porque estava adoentada e que precisava ficar em casa. Posteriormente, começou a trabalhar no Colégio Cearense, um pouco antes de terminar seu curso na Unifor, a convite de uma professora chamada Solange. Fora indicada para ensinar em uma turma de 5a série (atual 6ㅇano) no referido colégio, porém, como iria iniciar o período dos estágios na faculdade, logo resolveu pedir demissão do novo emprego.

'Sou muito ocupada, vou dar aula na disciplina de estágio pela UECE e nem sempre as aulas coincidem com o horário, eu vou ter que ficar pedindo o irmão para sair, então não dá certo eu ficar no seu colégio'. Ele falou: 'Eu aprendi com meu avô que pessoa ocupada é que tem tempo de fazer as coisas, porque organiza e faz. Gente desocupada não sabe'. Depois dessa, fiquei sem argumento, continuei calada. Aí depois ele falou: 'Vou fazer um trato com você. Você vem aqui todo dia, mas você vai optar por um expediente, de manhã ou de tarde'. E eu disse: 'De manhã, impossivel, porque a universidade geralmente me lota de manhã'. $E$ ele falou: 'Pois então você fica aqui à tarde'. Aí pronto, fui para a coordenação da $4 \underline{a}$ série [atual 50 ano]. Eram seis turmas. Consequentemente, era só professora que trabalhava com a gente, 15 professoras só na 4a série. Eu passei dois anos na coordenação. 
Os gestores acordaram com Célia para que ela fizesse o estágio da licenciatura na instituição e continuasse vinculada ao Colégio Cearense. Célia ressalta que aprendeu muita coisa durante o estágio, tanto na observação em salas de outras docentes como no período da regência.

Terminado o curso superior em dezembro de 1977, em setembro de 1978, Célia foi assumir, na UECE, as turmas da professora Solange - a mesma que havia Ihe convidado para trabalhar no Colégio Cearense -, que, adoecida, pediu que Célia a substituísse como docente do ensino superior. Célia aceitou prontamente o desafio, no entanto continuou lecionando no Colégio Cearense, pois o pagamento na UECE atrasava muito, até seis meses; dependia do Governo. Por diversas vezes, só na assinatura do contrato do semestre seguinte era que recebia os proventos atrasados. Logo, essa era uma renda com a qual não poderia contar sempre, por isso considerava tal ocupação como "um bico".

Em relação a essa substituição, Solange Ihe entregou seus planos de aulas para serem utilizados e seguidos tanto na turma da manhã quanto na turma da noite. Entretanto Célia tinha conviç̧ão de que não poderia dar a mesma aula nas duas turmas, isso porque ela tinha conhecimento das dificuldades do público noturno, que era composto por alunos mais cansados, que trabalhavam o dia todo. Dessa maneira, Célia realizou os ajustes e conseguiu exercer um bom trabalho. Inclusive, acrescenta que essa cultura de adaptar as aulas para o público noturno da UECE perdura até os dias atuais.

No período de 1978 a 1983, Célia substituiu Solange e assumiu as disciplinas de Política e Programas e Planejamento Educacional. No entanto seu vínculo era de professora colaboradora, que era aquela que entrava em março e saía em junho, não gozando de férias nem de décimo terceiro: era prestadora de serviços. Apesar disso, ela imprime importância a essa experiência quando comenta que assim foi ganhando seu espaço. 


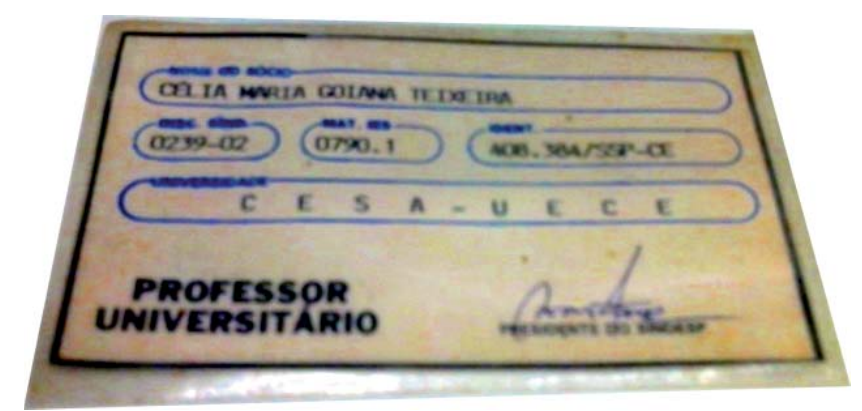

Imagem 2 - Carteira de identificação como professora

Fonte: Arquivos pessoais da entrevistada.

A rotina de atividades de Célia era muito intensa. Sobre isso, ela conta, com riqueza de detalhes, um incidente que lhe que aconteceu, o qual, segundo ela, nunca esquecerá:

Teve uma vez que cheguei atrasada em uma reunião [no Colégio Cearense], e ele [o irmão] foi me receber no elevador e falou: 'Célia, você gosta de pessoas diretas?'. E eu disse que sim. E ele me perguntou por que eu estava chegando àquela hora. Eu respondi: 'Porque eu dormi irmão, não consegui acordar. Eu estou num ritmo muito grande de trabalho, e o sono me pegou. Sinto muito, desculpe. E fique à vontade para fazer o que o senhor quiser comigo'. Ele mandou eu ir para a sala. Não havia ninguém presente, mas depois todo mundo ficou sabendo, não sei como essas coisas acontecem, e ficavam dizendo que eu era a protegida. Quando a Solange [colega de trabalho] falou que ia embora, que ia fazer mestrado, ele disse que aceitava a decisão dela. Logo todos queriam saber se ele já tinha uma substituta, e ele respondeu que tinha. Logo, todos quiseram saber, e ele respondeu: 'A professora Célia Goiana'. Quando ouvi, fiquei sem chão. Se eu procurei, eu não achei. Fiquei surpresa porque até então ele não me havia comunicado nada.

Para Célia, as coisas não fizeram sentido naquele momento, mas depois foram clarificando-se. Ela começou a observar o tipo de profissional que ela era: gostava das coisas corretas, organizadas, era responsável e sempre ajudava quando podia. "Tenho a impressão de que foi nesse momento que ele viu meu lado administrativo. Eles não se enganam à toa". Célia afirma que o Colégio Cearense foi seu laboratório, pois era uma escola particular, famosa e exigente onde aprendeu muito.

No que concerne à valorização de sua profissão, ela leciona:

O prêmio de quem é organizada e competente é mais trabalho. Após isso, fui dar aula de gestão escolar. Estudei bastante sobre gestão, e isso foi uma 
grande porta para eu assumir a vice-direção do Colégio Cearense. Na UECE, meus alunos também me valorizavam bastante, era muito querida por eles, a falta de valorização era no âmbito político. Minha valorização veio através de mim e dos meus alunos. Eu até fui eleita na 25 de Março [UECE] para ser coordenadora sem ao menos ser inscrita. Todos eles votaram em mim, foi de grande satisfação para mim, fiquei muito feliz. Quem me sustentou foi o Colégio Cearense; minhas filhas estudaram lá desde o maternal até o 30 ano [atual 3a série do ensino médio], e eu nunca paguei nada. Valeu a pena ser professora, por amor, pelo meu estudo e pelos meus alunos. [...]. Se fosse para escolher entre Medicina e Pedagogia, escolheria Pedagogia novamente.

Sua atuação no Colégio Cearense foi muito expressiva, tal exercício Ihe rendeu inclusive prêmio de homenageada, como se comprova adiante:

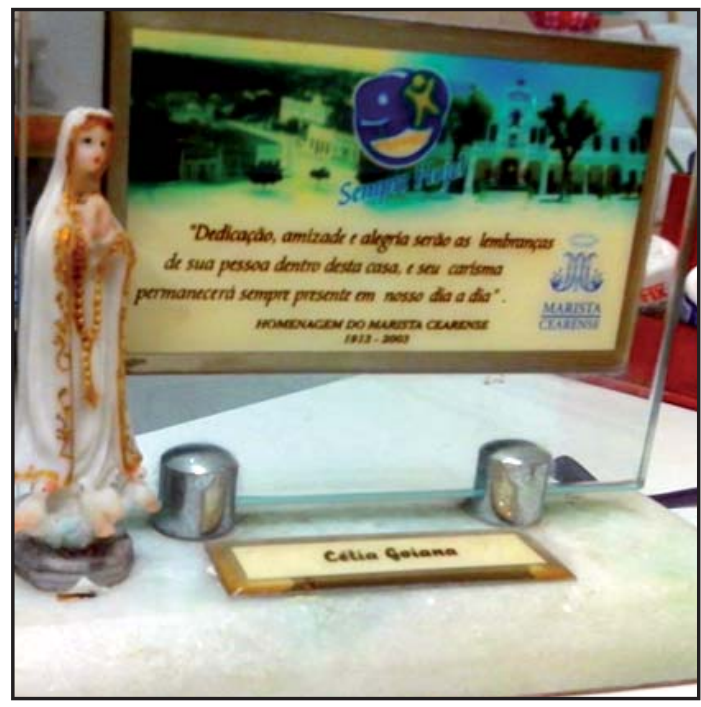

Imagem 3 - Homenagem prestada a Célia Goiana pelo Colégio Marista Cearense

Fonte: Arquivos pessoais da entrevistada.

Em 1982, Célia casou. Tendo em vista os padrões da época, em que as jovens casavam, em sua maioria, por volta dos 18 anos, casou tarde. Ela comenta que namorou seu marido por 14 anos. No tocante à família, ela relata como conseguiu dar conta:

Não tinha tempo para filho nem marido. Quando a minha primeira filha nasceu, eu voltei ao trabalho um mês antes [do fim da licença de quatro meses]. Quando tive a segunda, era outro diretor, esse me deixou mais de seis meses [liberada], 
quase um ano, eu só ia ao colégio pela manhã. Depois disso, eu tinha as titias, que as olhavam, e também tinha duas empregadas, uma para cuidar das crianças e outra para cuidar da casa e da comida. Era um desfile de empregada e babá, que, todo dia, quando chegava, era uma reclamação. Mas, assim mesmo, deu certo. Quando elas chegaram à idade da alfabetização, que foram para o colégio, para mim era uma verdadeira tranquilidade, estava perto delas o tempo inteiro.

Por volta de 1983, houve uma mobilização por melhorias na UECE, nessa época, não havia greve, falava-se diretamente com o governador, que, naquele momento, era Virgílio Távora. Célia comenta que, concomitantemente às suas atividades, participava das mobilizações e era professora de artesãos, financiada pela mulher de Virgílio Távora. A culminância dessa mobilização foi a realização de um concurso para professor efetivo da UECE, no qual Célia obteve aprovação. Ressalta que, ainda nesse período, o Curso de Pedagogia funcionava na Rua 25 de Março e que, somente em 1985, foi transferido para o Bairro do Itaperi.

Em 1987, logo após o nascimento de sua primeira filha, a Unifor abriu processo seletivo para professor, concurso no qual Célia também foi aprovada. Ela narra:

Tinha uns 50 candidatos para uma vaga. Eu passei. Só que eram duas disciplinas, aí a pessoa que tirou 2ㅇ lugar era 'peixão'. Quando eu soube, eu já fui falar com o coordenador, levei uma proposta, porque eu vi que dar duas disciplinas era pesado. Aí eu disse: 'Olha, nesse semestre eu divido pela entrada do concurso, mas no próximo eu quero a carga horária completa'. Aí deu tudo certo, fizemos um documento registrando tudo, todo mundo ficou feliz.

Após dois anos atuando como professora, por não considerar o salário da Unifor bom e por morar distante do campus, foi conversar com a coordenadora para dizer que iria sair da instituição. Segundo Célia, ao tomar ciência dessa notícia, a coordenadora falou: "Você é doida por trocar uma instituição como a Unifor pela UECE". Mas Célia estava decidida e não voltou atrás, pediu demissão para continuar só na UECE, porque tinha que se aposentar.

Imediatamente após sua saída da Unifor, foi eleita vice-diretora do Colégio Cearense. A respeito da soma de mais essa atividade à sua vida, assim ela exprime suas dificuldades: "Aí o sufoco foi grande, eu fiquei na UECE à noite, de segunda a sexta. Eu tinha 20h, depois faltou professor, daí virou 40h". Além disso, ela tinha que estar no Colégio Cearense durante os turnos da manhã e da tarde.

Sobre a formação continuada, Célia relata:

Aí depois eu fiz minha especialização na Unifor, em Educação Infantil, porque eu me sentia defasada com relação a esse conteúdo e eu trabal hava muito com 
essa clientela pequena. Então, fiz só a especialização, não me interessei em fazer mestrado. Ainda me inscrevi uma vez na federal e descobri que lá tinha na época uma história de frequentar um curso, quem não frequentasse o curso não passava. Aí fiz para cá [UECE] duas vezes. Na primeira, eu não passei. Na segunda vez, eu tive uma crise de hipertensão; eu sai daqui sem dizer nada a ninguém, peguei meu carro e não sei como cheguei em casa. Aí eu cheguei em casa e comecei a pensar: 'Estou precisando disso para quê? Para ganhar mais dinheiro, não é! Para trabalhar mais do que eu já trabalho?'. Não! Porque quando eu me dedico, eu me dedico. Aí ia fazer de conta, só para ter mestrado!

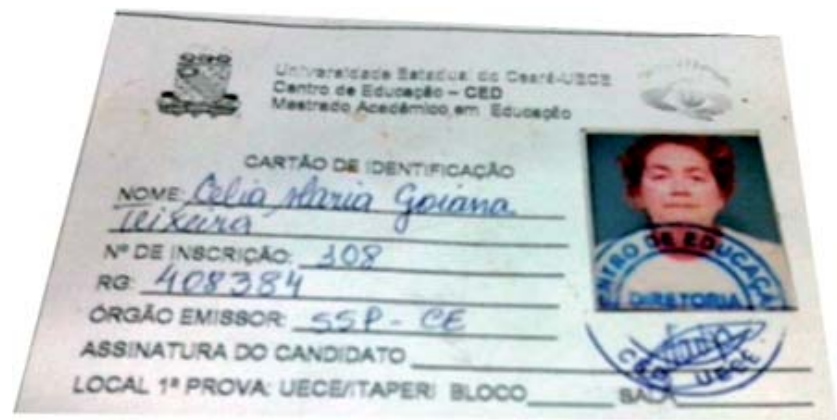

Imagem 4 - Cartão de identificação para a 1a etapa da prova do Mestrado na UECE

Fonte: Arquivos pessoais da entrevistada.

Não muito depois desse acontecimento, o setor de recursos humanos da UECE solicitou os documentos de Célia e considerou equivalente ao nível de mestrado um curso de 120 horas que ela havia realizado como descreve a educadora:

Foi quando mandaram pedir todos os meus documentos, aí eu tinha 120 horas de um curso que eu tinha feito, de especialização, a nível superior. Eu fiz na Paraíba, durante um mês, pelo Marista, tinha certificado e tudo. Aí me ligaram daqui. A partir daí, eu passei a ser assistente, com mesmo nível de mestrado. Então, financeiramente, é como se eu tivesse mestrado. Aceitaram essa minha titulação.

Na perspectiva de professorada entrevistada, em relação às atividades por ela desenvolvidas, enfatiza que tinha uma linha de trabalho que seguia e o que considera mais importante:

Não olhar o aluno como uma massa, como uma multidão, e principalmente não ditar regras sem sentido, sem dizer: 'Bom foi Piaget; foi fulano; foi beltrano'. Não, todos deram sua contribuição; deem valor às histórias dos outros, conheçam 
as histórias, não tem quem foi o mais certo, quem foi o mais errado, teve quem contribuiu. Conheçam as histórias para fazer sua crítica, vão pegando as contribuições. A minha linha de trabalho sempre foi assim, referencial.

Finaliza relatando uma de suas maiores dificuldades:

A maior dificuldade, se eu posso chamar isso de dificuldade, é a falta de recursos materiais, humanos, infraestrutura. Muito se fala da falta de recursos materiais, mas e a de humanos? Se eu tenho uma sala que não cabe a professora e 50 alunos, por que não ter duas salas que comportem 25?

Depois de suas duas filhas biológicas já terem ingressado na faculdade, Célia resolveu "criar" uma terceira. E conta como resolveu "adotar" a outra filha:

Na época, a campanha da fraternidade era 'Adote uma família'. Aí eu adotei. Do meu dinheiro, sobrava $R \$ 200,00$ [valor aproximado na moeda atual]. Teve umas férias que fomos para a serra, e eu propus a meu marido que adotássemos uma família. Aí nós adotamos. Era uma família desestruturada. A mãe é perturbada da cabeça, é cleptomaníaca. O pai tem um temperamento forte. Quando ele se zangava, ele batia tanto nessa menina! Ele dava 'peia' nela com facão. Ele era cortador de cana. Ela tinha as marcas das tiras nas costas. Ela era uma cobra [referindo-se à filha de criação], respondona, malcriada e cheia de vontade. Aí eu adotei a família para ajudar. Fomos comprando as coisas para a casa. Quando ela tinha 12 anos, a vó dela pediu para que ela viesse morar comigo, porque tinha medo de que ela virasse mulher da vida. Ela chegou totalmente desestruturada. Eu não fiz isso para mostrar nada a ninguém. Fiz porque achei que devia. Eu achava que era certo. Minha formação foi sempre voltada para a comunidade por influência de minha avó. Minha avó todo ano casava [preparava os casais nos cursos de noivos] 20 casais e ensinava 50 crianças para o catecismo e comunhão.

O marido de Célia é Engenheiro Auditor da Receita Federal aposentado, ganha líquido cerca de $\mathrm{R} \$ 10.000,00$, dinheiro que, para Célia, é pouco.

Considerando o padrão financeiro proporcionado pelo pai e posteriormente mantido com os empregos no Colégio Cearense e na UECE, apesar de o marido ganhar muito bem se comparado à maioria da população cearense e brasileira, ela ainda considera o salário de seu cônjuge insuficiente, o que permite inferir quão elevado era o nível financeiro de Célia. Ela acrescenta que sempre ganhou mais do que o marido e que, se não fosse pelo dinheiro dela, não teriam o patrimônio que possuem hoje.

Profissionalmente, outro acontecimento que marcou sua trajetória docente foi sua aproximação a Lia Matos, então coordenadora do Curso de Pedagogia da 
UECE, quem teve que se ausentar da coordenação por certo período em razão do adoecimento de um irmão. Nessa situação, dadas às circunstâncias, Célia acabou assumindo a coordenação do referido curso no lugar de Lia, mesmo não querendo ser coordenadora. Célia relata:

Foi outro desafio, aprender tudo o que eu não sabia. Depois de um tempo, foi quando eu descobri o câncer, mas eu já estava no final da minha carga horária. Aí me acostumei a ficar aqui de manhã, tarde e noite. Se eu fosse botar a UECE na justiça por hora extra, pense! [risos].

Um fato importante mais atual que marcou a vida de Célia foi ela ter sido diagnosticada com câncer de mama. Tal agravo na saúde lhe permitiria, com amparo legal, aposentar-se com remuneração integral, sem dedução de imposto de renda. Apesar disso, demonstrando seu amor pela profissão, ao contrário de abdicar de suas obrigações profissionais, optou por continuar exercendo as atividades docentes. Ela explica que:

Não atrapalhou em nada. Quando eu estava na coordenação, eu tinha disciplinas. Era gestão escolar. Tinha duas cadeiras de estágio. Quando descobrio câncer, já estava quase no final de minha carga horária, faltavam umas duas aulas. De um mês para o outro, teve uma diferença milimétrica, mas a doutora se preocupou. Ela o queria solto. Ele não tinha raiz, não estava agregado a nada, mas era maligno. Aí, em outubro, falei com a Lia Matos [coordenadora do Curso de Pedagogia] que eu ia avisar aos alunos que ia me operar. Fui à sala, comuniquei à turma, e eles me confortaram tanto! Sabiam que eu iria voltar, mas que iria demorar. Eu operei. Nesse período, teve uma greve. Quando eu voltei, a coordenação já estava com a Margarete Sampaio. Aí não fui mais lotada em sala de aula [ficou dando suporte à coordenação].

Mesmo com a nova gestão aconselhando-lhe que repousasse ao longo do tratamento contra o câncer ou até para que pedisse aposentadoria, Célia insistia em ir trabalhar. Entre as sessões de quimioterapia e radioterapia, sempre que melhorava dos efeitos colaterais, fazia-se presente na UECE, sempre disposta a colaborar. Essa ocupação, pela qual nutre um amor enorme, já não era apenas uma atividade profissional ou uma fonte de renda, mas uma necessidade para que ela pudesse ultrapassar as barreiras físicas e emocionais que a doença lhe impunha.

A surpresa final é que, não tão distante de um convite para a aposentadoria, Célia conclui o tratamento e é convidada para assumir a vice-coordenação do Curso de Pedagogia. Mesmo com a saúde ainda debilitada e com as limitações impostas pelo avançar da idade, aos 64 anos, ainda se dispôs a colaborar com o Curso de Pedagogia da UECE, dedicando-se a abarcar tamanha carga de trabalho. 


\section{CONCLUSÃO}

As memórias de Célia Goiana foram produto de um trabalho de ressignificação tecido pela amálgama entre presente e passado, que veio à tona à medida que foi fabricado, sem necessidade de linearidade (LE GOFF, 2008). Tal elaboração requereu tratamento teórico e metodológico por parte daqueles que se dedicam à coleta das lembranças. A história oral, como metodologia de investigação científica, foi considerada, no âmbito da pesquisa qualitativa, poderoso instrumento para a descoberta, a exploração e a avaliação de como Célia Goiana compreende seu passado, vincula sua experiência individual a seu contexto social, interpreta-a e dá-lhe significados a partir do momento presente (MINAYO, 2006).

A vida de todo indivíduo, seja anônimo, seja popular, possui um valor autônomo para a história, e a trajetória de Célia Goiana, produto de individualidades únicas e irredutíveis, contribui para a compreensão da história da educação. A elaboração de biografia sobre a referida educadora possibilita questionar e preservar a história e a memória da educação no Ceará na primeira metade do século XX. Loriga (2011, p. 112), ao estudar Meyer e Droysen, leciona: “O passado não é um patrimônio perdido que deve ser recuperado, mas uma herança viva, uma força, uma energia geradora de sentido".

Biografar a educadora Célia Goiana não possibilitou esgotar a história da educação no Ceará, mas permite: refletir sobre essa tessitura histórica; compreender melhor suas especificidades e regionalidades; elaborar um acervo com estudos biográficos de viés educacional; preservar a memória e história da educação no Ceará; destacar e valorizar a cultura e a história social locais; produzir novas fontes e incentivar novas pesquisas.

Não podemos negar que as contribuições de Célia Goiana à educação foram de valia e que seu exemplo de vida, como mulher, esposa, filha, mãe e, sobretudo, educadora, merece atenção, especialmente daqueles inseridos no âmbito educacional. Na condição de mulher que se dedicou com afinco à profissão docente, atuando: na educação infantil, com alfabetização de crianças; no ensino fundamental, com escolas em comunidades carentes e em colégios mais elitistas; e no nível superior, com formação de profissionais para o magistério, Célia não apenas ajudou a alfabetizar crianças, a desenvolver a criticidade de adolescentes e a formação profissional de adultos, ela se fez sujeito da história de educadores que contribuíram para o desenvolvimento do cenário educacional cearense. Sua história de vida se imbrica com a de 
inúmeros outros profissionais e possibilita, a partir da (auto)biografia, identificações e rupturas que vão gerar novas reflexões e narrativas históricas.

As discussões não se esgotam aqui, ao contrário, propõem-se para estimular novos estudos, pois, como afirma Xavier (2014, p. 230), "[...] o incentivo fica pautado para que muitas outras pesquisas, de cunho biográfico, venham à tona fazendo emergir os até então anônimos ofuscados, esquecidos ou menosprezados pela história vista de cima".

\section{REFERÊNCIAS}

ARIÈS, P. História social da criança e da família. Rio de Janeiro: Guanabara, 1978.

BOSI, E. Memória e sociedade: lembranças de velhos. 3. ed. São Paulo: Companhia das Letras, 1994.

BURKE, P. (Org.). A escrita da história. São Paulo: Unesp, 1992.

CERTEAU, M. A escrita da história. 2. ed. Rio de Janeiro: Forense Universitária, 2002.

CHARTIER, R. A história cultural: entre práticas e representações. Lisboa: Difel, 1988.

FERREIRA, M. M.; AMADO, J. Usos \& abusos da história oral. 8. ed. Rio de Janeiro: FGV, 2006.

FIALHO, L. M. F. Biografia de um jovem traficante: brigas de gangues e homicídios em série. Fortaleza: Edições UFC, 2015.

LE GOFF, J. História e memória. Campinas, SP: Unicamp, 2008.

LORIGA, S. O pequeno x da biografia à história. Belo Horizonte: Autêntica, 2011.

MACHADO, C. J. S. M. A dimensão da palavra: práticas de escrita de mulheres. João Pessoa, PB: UFPB, 2005.

MALUF, M.; MOTT, M. L. Recôndito do mundo feminino. In: SEVCENKO, N. (Org.). República: da belle époque à era do rádio. São Paulo: Companhia das Letras, 1998. p. 368-421. (História da vida privada no Brasil, 3).

MEIHY, J. C. S. B.; HOLANDA, F. História oral: como fazer como pensar. São Paulo: Contexto, 2007.

MEIHY, J. C. S. B.; RIBEIRO, S. L. S. Guia prático da história oral. São Paulo: Contexto, 2011.

MINAYO, M. C. S. O desafio do conhecimento: pesquisa qualitativa em saúde. 9. ed. São Paulo: Hucitec, 2006.

SILVA, K. V. Dicionário de conceitos históricos. 2. ed. São Paulo: Contexto, 2009.

TURATO, E. R. Tratado da metodologia da pesquisa clínico-qualitativa. Petrópolis, RJ: Vozes, 2003. 
XAVIER, A. R. Joana Paula de Morais (1900-1963): história, memória e trajetórias educativas. Fortaleza: Imprece, 2014.

\section{Sobre as autoras:}

Lia Machado Fiuza Fialho: Professora Adjunta do Centro de Educação da Universidade Estadual do Ceará (UECE). Docente do Programa de Pós-graduação em Educação (PPGE/UECE). E-mail: lia_fialho@yahoo.com.br

Scarlett O'hara Costa Carvalho: Mestranda em Educação pelo Programa de Pós-Graduação em Educação da Universidade Estadual do Ceará. Bolsista CAPES. Integrante do grupo de pesquisa "Práticas Educativas, Memória e Oralidades". E-mail: scarlettoharacc@gmail.com

\section{Recebido em julho de 2016.}

Aprovado para publicação em junho de 2017. 
